\title{
CHARACTERIZATION OF SOIL THERMAL PROPERTIES FOR DESIGN OF UNDERGROUND CABLE ROUTES AT THE WIND FARM POWER PLANT AREA, PANYIPATAN AND PELAIHARI SUB-DISTRICT, SOUTH KALIMANTAN
}

\author{
Syamsurijal Rasimeng \\ Department of Geophysical Engineering, Faculty of Engineering, University of Lampung, Indonesia \\ *Corresponding author. Email: syamsurijal.rasimeng @eng.unila.ac.id
}

Manuscript received: 9 March 2020; Received in revised form: 27 April 2020; Accepted: 30 April 2020

\begin{abstract}
The estimation of soil thermal resistivity is essential for many types of big engineering projects because of the required knowledge about subsurface transmission of either heated fluids or high power currents. Thermal conductivity measurements were carried out at 12 locations, eight measurement point locations in South Kalimantan, the Sapu Angin hill region, sub-district Panyipatan and four points in the area of Kampung Baru, sub-district Pelaihari made at $2-3$ variations in depth of 50 to $100 \mathrm{~cm}$, which adjusted to the ability of the soil drilling support equipment to make holes in the soil. Samples were also collected from the locations for physical parameters description that influences thermal resistivity, subjected to grain size distribution and compaction analysis. The calculation of thermal conductivity is done by using CT-Lab software ver. 1.0.2 with a sensor resistance value of $82.69 \Omega / \mathrm{m}$, heater voltage $4.0 \mathrm{~V}$, and heater power $4.3857 \mathrm{~W} / \mathrm{m}$. The results show that the thermal conductivity values range from 0.593 to $3.239 \mathrm{~W} / \mathrm{mK}$. For the Sapu Angin hill region, sub-district Panyipatan, soil layers are generally in the form of sandy-clay $(\lambda>1.2 \mathrm{~W} / \mathrm{mK})$, but at some points, the value of thermal conductivity in these layers have decreased $(\lambda<1.2 \mathrm{~W} / \mathrm{mK})$ due to rainwater infiltration (BH-02, BH-03, BH-04, BH-05, and BH07). The infiltration causes weakening or loosening of bonds between the constituent particles of the soil. While in the area of Kampung Baru sub-district Pelaihari, the soil layer is generally in the form of sandy-clay, which has not well compacted (BH-08, BH-10, BH-12) with high water content (BH-09).
\end{abstract}

Keywords: power plant; soils thermal resistivity; underground cable; wind farm.

\section{Introduction}

The estimation of thermal resistivity of soils is essential for many kinds of engineering projects. Many researchers have demonstrated that soil thermal resistivity is a property of the soil that depends on various parameters such as type of soil, particle size distribution, and compaction characteristics. Hence, its estimation based on existing empirical and mathematical models is difficult. A generalized relationship experiment for estimating the soil thermal resistivity can be obtained by knowing the dry density, moisture content, and percent size fraction of the various particle sizes, and validation of the proposed generalized equations with the results available in the literature (Dali Naidu and Singh, 2004).

In 2015, an evaluation study for thermal soil classification had been carried out for high voltage direct current projects with buried cable (Lilliestierna and Utas, 2015). The cable route of the South West Link project investigated in order to find potential hotspots where the soil's thermal 
resistivity is high since the temperature of the cable is critical. If the designed maximum temperature exceeded, it shortens the life length of the cable, and the warranty is no longer valid. The cable will also lose effect at high temperatures.

Rock temperature measurements above $1800 \mathrm{~m}$ elevations in the Southern Carpathians, describe the occurrence patterns of both diurnal and seasonal frost in different topographic conditions (exposure, altitude) as a stage in evaluating frost weathering susceptibility (Vasile and Vespremeanu-Stroe, 2017). Soil thermal conductivity predictive models concerning the advantages, disadvantages and application conditions on sands were conducted by predicting sand thermal conductivity and comparing with the measured values collected from literature, base on linear regression analyses and rootmean-square error (RMSE) analyses performed to evaluate further the model performance (Zhang and Wang, 2017).

Based on geological data and information on installed cable types, a stretch with potential hotspots was found south of Ljungby, where a field study is conducted. Potential hotspots are where the thinner cable type located in dry soil, which classified as thermal soil class B in this study. These results show that coarsegrained soils with low water content have low thermal conductivity. Soil samples classified as both coarse and dry have an average $40 \%$ lower thermal conductivity compared to the mean of all samples. The field measurements of thermal conductivity resulted in an average of $1.21 \mathrm{~W} / \mathrm{mK}$, where the $5^{\text {th }}$ percentile is $0.66 \mathrm{~W} / \mathrm{mK}$, and the $1^{\text {st }}$ percentile is $0.43 \mathrm{~W} / \mathrm{mK}$.

The investigation of the temperature of the cable costs a lot since the landscape often has very varied conditions along the stretch with different thermal properties (Dali Naidu and Singh, 2004), (Lilliestierna and Utas, 2015), (Sundberg, 1988). In designing the cable route for the maximum acceptable temperature, it is not the average temperature along the stretch that is used. The cable must meet the full temperature requirements for every section of the route down to a scale of 1 to $5 \mathrm{~m}$. Therefore, the cable needs to be designed for the section with the highest thermal conductivity.

A limited section with coarse-grained sand and low groundwater level can be the designer's land in areas where the remainder consists of silty. The main factors affecting cable temperature are a cross-sectional area of the conductor, cable separation, cable depth, thermal conductivity of the soil, the electrical effect of the cable, and ground temperature. The main factors affecting the thermal conductivity of the soil are water content, density, mineral type, and organic content.

The relationship between thermal conductivity, heat capacity, and thermal diffusion showed in Eq. (1). Thermal conductivity $\lambda(\mathrm{W} / \mathrm{mK})$ is the ability of the material to transfer heat, and the heat capacity $C\left(\mathrm{~J} / \mathrm{m}^{3} \mathrm{~K}\right)$ depends on the material's ability to storing energy. Thermal diffusivity $\kappa\left(\mathrm{m}^{2} / \mathrm{s}\right)$ is the ability to even out temperature differences within the material.

$\lambda=\kappa C$

There are significant variations in the thermal conductivity of different soils, which mainly depend on the porosity, grain size distribution, and the water content. Soils with high porosity have low heat conductivity because of the low thermal conductivity of air. The impact of water content in soil is vital since it replaces air and therefore increases thermal conductivity in the soil. This is especially true for the contact surfaces between grains where the water acts as a bridge for heat transport. The porosity depends on grain size and compaction ability, which makes the coarse soils less heat conductive. 
Soil is a solid particle that bound and connects each other at a relatively small contact point where the cavity between the particles can contain air or water. Whereas in dry soil conditions, the cavity between the particles is filled with air, as shown in Figure 1. If the cavity begins to fill with water, the effective contact area between the particles increases, thereby increasing heat conduction, this will cause a decrease in the thermal resistivity of the soil. In consequences, an increase in water content will cause a decrease in soil resistivity, and when the soil dries up, the thermal resistivity will increase (Malmedal et al., 2014).

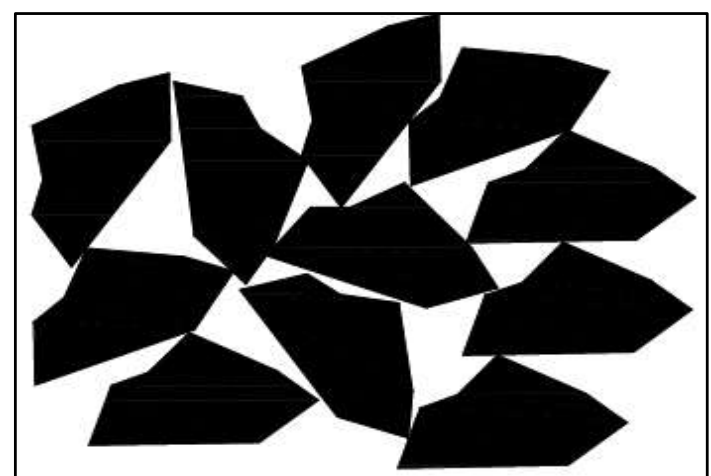

Figure 1. Soil particles with voids (Malmedal et al., 2014).

Large grain size distribution tends to leads to high thermal conductivity since it increases the compaction ability. The thermal conductivity of clay differs depending on the water content (Sundberg, 1988). Clay with high water content has a thermal conductivity of 0.85 to $1.10 \mathrm{~W} / \mathrm{mK}$. Close to the ground surface, it is common that clay is in a drier state called crust clay. This clay has a thermal conductivity of 1.1 to $1.4 \mathrm{~W} / \mathrm{mK}$. The density of the crust clay is higher than the underlying unaffected clay (Sundberg, 1988).

In peat area, the conductivity is very low above the groundwater table due to its high porosity. The porosity of approximately $90 \%$ gives a conductivity of 0.2 to 0.6 $\mathrm{W} / \mathrm{mK}$. Below the groundwater table, the conductivity of peat is almost the same as for water, which is $0.6 \mathrm{~W} / \mathrm{mK}$. The rate of humus is also a factor for the conductivity. Peat with low humus content has a lower water holding capacity, which decreases the thermal conductivity.

The thermal conductivity of rocks depends on the degree of metamorphosis and the mineral composition. For common rock types are granite and gneiss, where $42.4 \%$ consist of granite, and $23.7 \%$ consist of gneiss (Sundberg, 1988). The average thermal conductivity of both these crystalline rock types is $3.5 \mathrm{~W} / \mathrm{mK}$. In Table 1. and Figure 2. the thermal conductivity value for some of the common components in soils are displayed,

Table 1. Summary of thermal properties of common components in soils (Zhang and Wang, 2017).

\begin{tabular}{lccc}
\hline Materials & $\begin{array}{c}\text { Density } \\
\left(\mathbf{k g} / \mathbf{m}^{\mathbf{3}}\right)\end{array}$ & $\begin{array}{c}\text { Heat } \\
\text { capacity } \\
(\mathbf{K J})\end{array}$ & $\begin{array}{c}\text { Thermal } \\
\text { conductivity } \\
(\mathbf{W} / \mathbf{m K})\end{array}$ \\
\hline Air $\left(10^{\circ} \mathrm{C}\right)$ & 1.25 & 1.00 & 0.026 \\
\hline Water $\left(25^{\circ} \mathrm{C}\right)$ & 999.87 & 4.20 & 0.59 \\
\hline $\begin{array}{l}\text { Water vapor } \\
(1 \text { atm, } 400 \mathrm{~K})\end{array}$ & - & 1.90 & 0.016 \\
\hline Ice $\left(0^{\circ} \mathrm{C}\right)$ & 917 & 2.04 & 2.25 \\
\hline Quartz & 2660 & 0.73 & 8.4 \\
\hline Granite & 2750 & 0.89 & $1.70-4.00$ \\
\hline Gypsum & 1000 & 1.09 & 0.51 \\
\hline Limestone & 2300 & 0.90 & $1.26-1.33$ \\
\hline Marble & 2600 & 0.81 & 2.8 \\
\hline Mica & 2883 & 0.88 & 0.75 \\
\hline Clay & 1450 & 0.88 & 1.28 \\
\hline Sandstone & $\sim 2270$ & 0.71 & $1.60-2.10$ \\
\hline
\end{tabular}

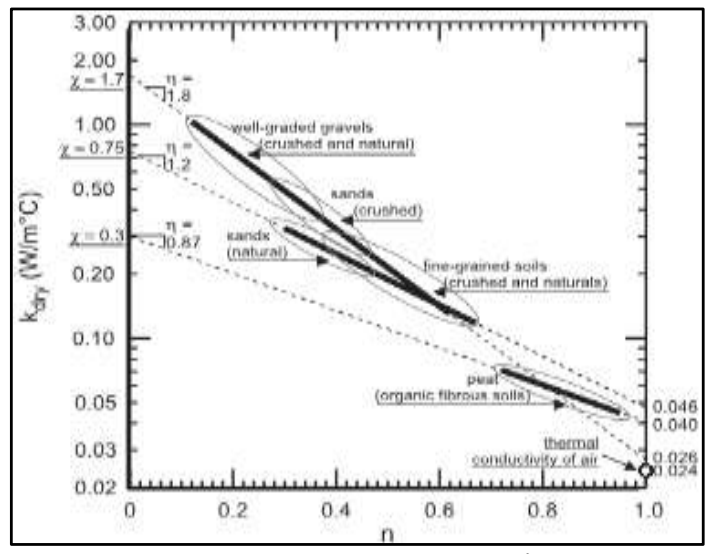

Figure 2. Influence of soil type on $\lambda_{d r y}$ (Côté and Konrad, 2005). 
In comparison with crystalline rocks, the sedimentary rocks are more dependent on the water content and porosity when deciding the thermal conductivity.

The thermal conductivity also depends on the age of sedimentary rock origins. The Mesozoic era lasted between $251-65.5$ million years ago, and the Cambro-Silur lasted in the period $542-416$ million years ago. Pre-Cambrium is a geological era that lasted between 4600 - 542 million years ago.

Soil water content is one of the significant factors affecting thermal conductivity. The lowest conductivities generally found above the groundwater table, especially in organic soils such as peat and loam. Finding low groundwater levels becomes interest when searching for a hotspot on the stretch that could be designing for the entire cable. The groundwater level depends on rainfall surrounding recharge conditions. It also varies over time, as it follows the hydrological cycle, and the degree of variation is affected by the aquifer's physical characteristics and dimensions. The groundwater table is lowest during summer and highest during the rainy season.

The natural temperature in the ground varies throughout the year, which makes certain periods have more implications for high cable temperatures, which need to be better designed. Besides the air temperature, the depth is also an essential factor to determine the ground temperature. The temperature variation decreases with an increased depth, which can be seen in Figure 3. This figure shows how the ground temperature fluctuates during the year in the Ljungby region at a depth of 0.5 and 1.5 $\mathrm{m}$ compared to the air temperature. The graph shows how the heat sluggish in the ground creates a phase shift of the annual air temperature variation. This phase shift increases with the depth until the ground temperature is not affected by the yearly temperature variations. In reality, the ground temperature variations depending on the groundwater table fluctuations. Furthermore, the figure does not take into account the extra energy needed for the transition between a frozen and unfrozen state in the ground, which leads to slower temperature variation (Lilliestierna and Utas, 2015).

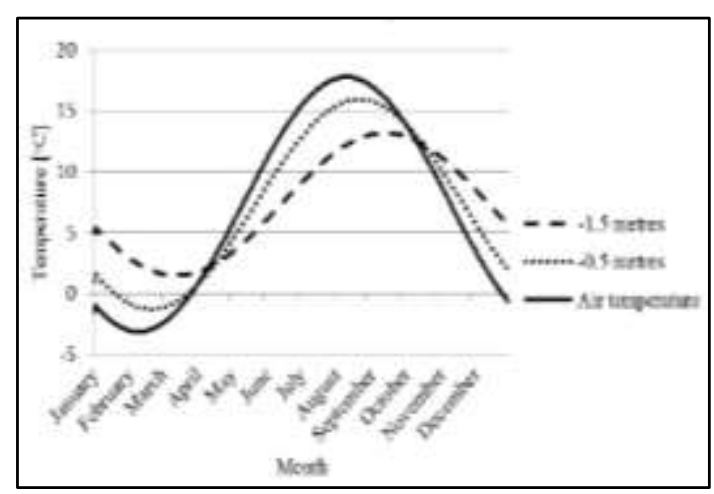

Figure 3. The annual ground temperature variation in Ljungby region (Lilliestierna and Utas, 2015)

The line chart is based on Equation (2) for temperature variations in the ground where $t$ is the time, and $z$ is the depth. Besides these variables, the formula contains $T_{\text {mean }}$ and $T_{\text {amp }}$, which is the mean temperature of the year and the most significant annual temperature amplitude, respectively. The formula also contains $t_{p}$, which is the day number when the highest temperature amplitude occurs during the year. Finally, $d$ decided by the thermal diffusivity of the soil $\kappa$ (Lilliestierna and Utas, 2015).

$$
\begin{gathered}
T(t, z)=T_{\text {mean }}-T_{a m p}\left(e^{z / d}\right) \cos ((t- \\
\left.\left.t_{p}\right) \frac{2 \pi}{365}-\frac{z}{d}\right) \\
d=\sqrt{2 \kappa /\left(\frac{2 \pi}{365}\right)}
\end{gathered}
$$

The temperature data is based on day mean values during ten years for the Ljungby region between 1997 until 2007. All input values for Figure 3. 


\section{Methods}

Measurement, data processing, and analysis of thermal conductivity of soil and rocks refer from the standard are issued under the fixed designation D-5334. This test method is under the jurisdiction of ASTM Committee D18 on Soil and Rock and is the direct responsibility of Subcommittee D18.12 on rock mechanics (American Society for Testing and Materials, 2005). This test method presents a procedure for determining the thermal conductivity of soil and soft rock using a transient heat method. The test method is applicable for both undisturbed and re-molded soil specimens as well as in situ and laboratory soft rock specimens. For satisfactory results in conformance with this test method, the principles governing the size, construction, and use of the apparatus described in this test method should be followed. If the results reported as having been obtained by this test method, then all relevant requirements prescribed in this test method shall be met.

The thermal conductivity determined by a variation of the line source test method using a needle probe having a considerable length to diameter ratio to stimulate conditions for an infinitely long specimen. The probe consists of a heating element and a temperature measuring element and inserted into the specimen. A known current and voltage are applied to the probe, and the temperature rise with time noted over a period of time. The thermal conductivity is obtained from an analysis of the approximately linear portion of the quasi-steady-state temperature-time response (American Society for Testing and Materials, 2005).

The apparatus shall (Figure 4.) consist of the following,

1. Thermal Needle Probe (MAE CTS45); A device that creates a linear heat source and incorporates a temperature measuring element (thermocouple or thermistor) to measure the variation of temperature at a point in the hole

2. Constant Current Source (Battery 1.5V); A device to produce a constant current.

3. Thermal Readout Unit (MAE A5000T); A device to produce a digital readout of temperature in degrees Celsius to the nearest $0.1 \mathrm{~K}$.

4. Voltage-Ohm-Meter (VOM); A device to read voltage and current to the nearest $0.01 \mathrm{~V}$ and ampere.

5. Timer, stopwatch, or similar instrument capable of time measuring to the nearest $0.1 \mathrm{~s}$ for a $300 \mathrm{~s}$.

6. Ancillary equipment, capable of drilling a straight vertical hole having a diameter as close as possible to that of the probe and GPS.
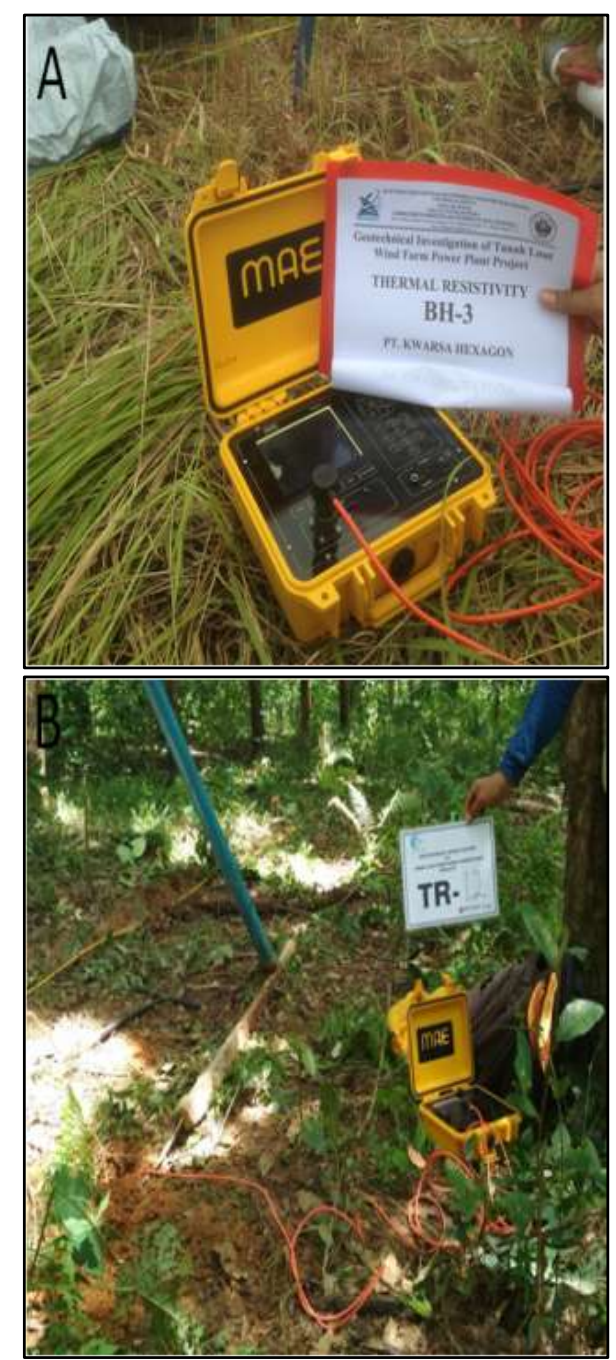

Figure 4. Thermal resistivity measurement at (A) BH-03 at Sapu Angin hill, sub-district Panyipatan and (B) BH-12 at Kampung Baru, sub-district Pelaihari. 
Measurements were carried out at 12 locations shown in Figure 5, made at $2-3$ variations in depth of 50,75 , and $100 \mathrm{~cm}$ respectively, which adjusted to the ability of the soil drilling support tool to make holes in the soil. Parameters and curve of data measurement at $\mathrm{BH}-01$ can be seen as in Table 2 and Figure 6, respectively.

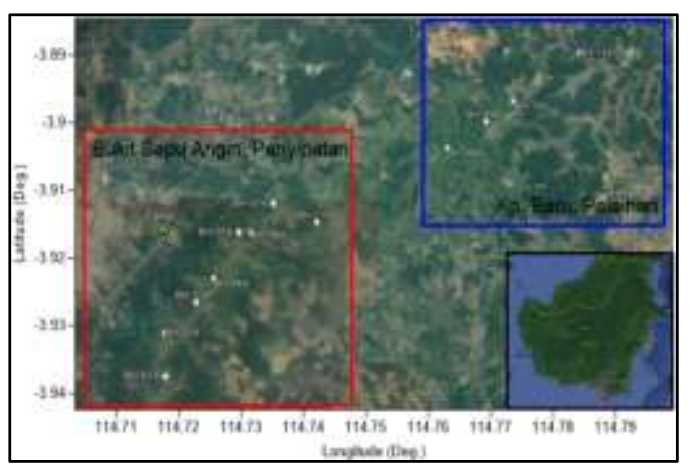

Figure 5. Twelve locations of thermal resistivity measurement at South Kalimantan, Sapu Angin hill, sub-district Panyipatan, and Kampung Baru, sub-district Pelaihari.

Table 2. Parameters of data measurement.

\begin{tabular}{ll}
\hline Location & $:$ BH-01 $(50 \mathrm{~cm})$ \\
\hline Latitude & $: 3.940386 \mathrm{~S}$ \\
\hline Longitude & $: 114.720574 \mathrm{E}$ \\
\hline Elevation & $: 266 \mathrm{~m}$ \\
\hline Sensor resistance & $: 82.69 \mathrm{Ohm} / \mathrm{m}$ \\
\hline Heater voltage & $: 4.5$ volt \\
\hline Heater power & $: 5.5555 \mathrm{~W} / \mathrm{m}$ \\
\hline Measurement time & $: 300 \mathrm{~s}$ \\
\hline Initial temperature & $: 33.3^{\circ} \mathrm{C}$ \\
\hline Final temperature & $: 25.14^{\circ} \mathrm{C}$ \\
\hline
\end{tabular}

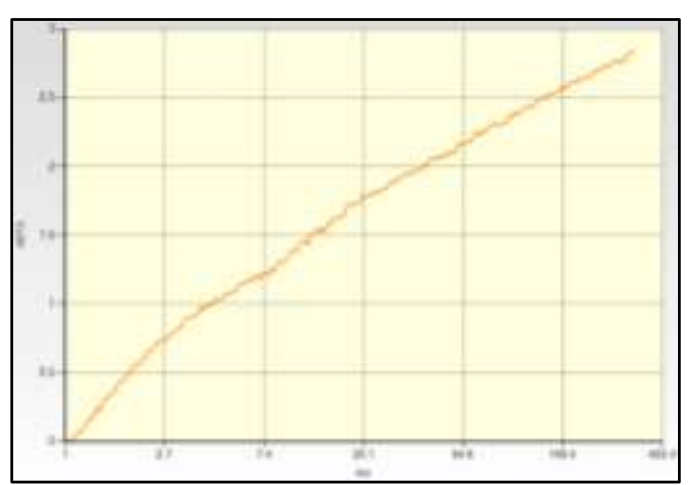

Figure 6. Curve of data measurement at $\mathrm{BH}-01$, depth of sensor is $50 \mathrm{~cm}$.

Calculation of the thermal conductivity $(\lambda)$ of the specimen from the linear portion of the experimental curve shown in Figure 7. using the following relationship (Malmedal et al., 2014), (van Rooyen and Winterkorn, 1957), (Herzen and Maxwell, 1959).

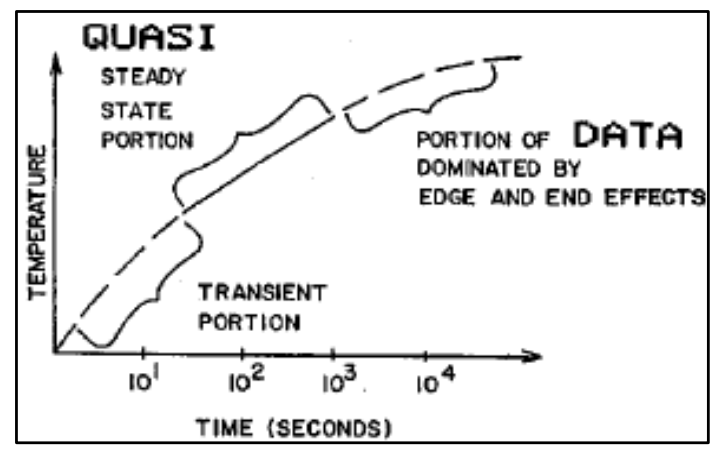

Figure 7. Typical Experimental Test Results Plotted on Semi-log Graph (American Society for Testing and Materials, 2005).

The calculation of thermal conductivity is done by using equations (4) and (5) using CT-Lab software ver. 1.0.2, with a sensor resistance value of $82.69 \Omega / \mathrm{m}$, heater voltage $4.0 \mathrm{~V}$, and heater power 4.3857 $\mathrm{W} / \mathrm{m}$. The results of the calculation of all location points and depth can be seen as in Table 3,

$\lambda=\frac{2.30 Q}{4 \pi\left(T_{2}-T_{1}\right)} \log _{10}\left(t_{2} / t_{1}\right)=$ $\frac{Q}{4 \pi\left(T_{2}-T_{1}\right)} \ln \left(t_{2} / t_{1}\right)$

where,

$Q=\frac{I^{2} R}{L}=\frac{E I}{L}$

\section{RESULT AND ANALYSIS}

Referring to Table 1. as a reference in determining rock material based on thermal conductivity values, and Figure 7. as the theoretical basis for calculating the value of thermal conductivity. So, the results of thermal conductivity calculations presented in Table 3. show variations of rock types that exist below the surface. For the Sapu Angin hill, sub-district Panyipatan, Soil layers are generally in the form of sandyclay $(\lambda>1.2 \mathrm{~W} / \mathrm{mK})$, but at some points, the value of thermal conductivity in these layers have decreased $(\lambda<1.2 \mathrm{~W} / \mathrm{mK})$ due to rainwater infiltration (BH-02, $\mathrm{BH}-03$, 
BH-04, BH-05, and BH-07). The infiltration causes weakening or loosening of bonds between the constituent particles of the soil.

At the $\mathrm{BH}-06$ and $\mathrm{BH}-11$ locations, the value of thermal conductivity has increased $(\lambda>2 \mathrm{~W} / \mathrm{mK})$ and is interpreted as a result of the presence of limestone minerals as part of the Pudak Formation. While with four measurement point locations in the area of Kampung Baru, sub-district Pelaihari, the soil layer is generally in the form of sandy-clay, which has not well compacted (BH-08, BH-10, BH-12) with high water content (BH-09).

The results of this study consistent with geological information, which shows that the study area is located in the Pudak Formation as part of the regional fold structure, from the Northeast to the Southwestern of this research area. This formation is composed of lava rock with conglomerate alternation with volcaniclastic breccia and sandstones with limestone olistolite, porphyritic basalt, ignimbrite, igneous rock, and ultramafic.

The weathering process occurs in hillintrusion landform. This area is dominated by low hills formed by the process of volcanic-igneous rock breakthrough, in the form of gabbro, diabase, diorite, granite, and basalt, among the hills-mountain folds of ultramafic and metamorphic (Darlan et al., 1999). The weathering process has been quite intensive, so the erosional process on the hill slopes is visible and causes the thickness of the sandy clay layer and the mixing of limestone rocks in the soil surface in the study area. Another thing that expected is the presence of water in the rock layers with high porosity so that it can replace the air filling the rock pores. Because water has a high thermal conductivity compared to air, it is advantageous with high groundwater levels in terms of keeping the cable temperature low.
Groundwater levels vary throughout the year, and it is essential to calculate the probability of extreme levels by looking at historical groundwater levels in the area.

Variations in the groundwater level lead to convection below the water surface. The thermal condition around the cable is heat sluggish, which means that it requires a long period of low heat convection in order to establish increased cable temperature. When the cable is located above the groundwater level, the evaporation rate of the soil and the distance from the groundwater level is crucial. The evaporation rate increases with is the waterholding capacity that depends on the capillary ability of the soil. A water retention curve illustrates how the waterbearing capacity of the soil reduces with increased water tension above the groundwater level.

In water retention curves, the volumetric water content is used. However, our acquired values will be stated in gravimetric water content. Gravimetric water content is the ratio between the mass of water and solid mass in a sample. Changes in water content over time are less for fine-grained soils such as clay and silt compared to more draining soils such as gravel and sand. Generally, soils with high organic content have a low heat convection capacity.

Variations in the groundwater level lead to convection below the water surface. The thermal condition around the cable is heat sluggish, which means that it requires a long period of low heat convection in order to establish increased cable temperature. When the cable is located above the groundwater level, the evaporation rate of the soil and the distance from the groundwater level is crucial. The evaporation rate increases with is the waterholding capacity that depends on the capillary ability of the soil. 
Table 3. Describes types of rock base on the result of thermal conductivity calculation.

\begin{tabular}{|c|c|c|c|c|c|c|c|c|}
\hline \multicolumn{2}{|c|}{ Location } & $\begin{array}{l}\text { Latitude } \\
\text { (Deg.) }\end{array}$ & $\begin{array}{c}\text { Longitude } \\
\text { (Deg.) }\end{array}$ & $\begin{array}{l}\text { Elev. } \\
(\mathbf{m})\end{array}$ & $\begin{array}{c}\text { Depth } \\
\text { (cm) }\end{array}$ & $\begin{array}{c}\text { Thermal } \\
\text { Conductivity } \\
(\mathrm{W} / \mathrm{mK})\end{array}$ & $\begin{array}{c}\text { Thermal } \\
\text { Resistivity } \\
(\mathrm{mK} / \mathbf{W})\end{array}$ & Description \\
\hline \multirow{17}{*}{ 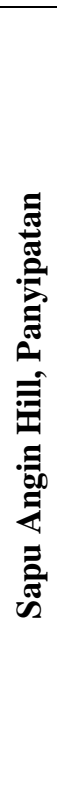 } & \multirow{2}{*}{ BH-01 } & \multirow{2}{*}{-3.940386} & \multirow{2}{*}{114.720574} & \multirow{2}{*}{266} & 50 & 1.232 & 0.81 & \multirow{2}{*}{ Sandy-clay } \\
\hline & & & & & 70 & 1.236 & 0.81 & \\
\hline & \multirow{2}{*}{ ВH-02 } & \multirow{2}{*}{-3.933006} & \multirow{2}{*}{114.720813} & \multirow{2}{*}{233} & 50 & 0.98 & 1.02 & \multirow{8}{*}{$\begin{array}{l}\text { Clay (with } \\
\text { water } \\
\text { content) }\end{array}$} \\
\hline & & & & & 100 & 0.887 & 1.13 & \\
\hline & \multirow{2}{*}{ ВH-03 } & \multirow{2}{*}{-3.929539} & \multirow{2}{*}{114.724677} & \multirow{2}{*}{295} & 50 & 0.848 & 1.18 & \\
\hline & & & & & 70 & 0.876 & 1.14 & \\
\hline & \multirow{2}{*}{ BH-04 } & \multirow{2}{*}{-3.925859} & \multirow{2}{*}{114.727076} & \multirow{2}{*}{254} & 50 & 0.898 & 1.11 & \\
\hline & & & & & 70 & 0.942 & 1.06 & \\
\hline & \multirow{2}{*}{ BH-05 } & \multirow{2}{*}{-3.91915} & \multirow{2}{*}{114.731751} & \multirow{2}{*}{224} & 50 & 0.911 & 1.1 & \\
\hline & & & & & 70 & 1.045 & 0.96 & \\
\hline & \multirow[b]{2}{*}{ BH-06 } & \multirow[b]{2}{*}{-3.918195} & \multirow[b]{2}{*}{114.733766} & \multirow[b]{2}{*}{207} & 50 & 2.423 & 0.41 & \multirow{2}{*}{$\begin{array}{l}\text { Sandy-clay } \\
\text { (with } \\
\text { carbonate) }\end{array}$} \\
\hline & & & & & 70 & 3.239 & 0.31 & \\
\hline & \multirow[b]{2}{*}{ BH-07 } & & & & 50 & 0.593 & 1.69 & Clay (with \\
\hline & & -3.913761 & 114.736962 & 197 & 70 & 0.678 & 1.48 & $\begin{array}{l}\text { water } \\
\text { content) }\end{array}$ \\
\hline & & & & & 50 & 2.41 & 0.41 & Sandy-clay \\
\hline & BH-11 & -3.916554 & 114.743841 & 34 & 75 & 2.055 & 0.49 & (with \\
\hline & & & & & 120 & 2.391 & 0.42 & carbonate) \\
\hline & & & & & 50 & 0.934 & 1.07 & \\
\hline & BH-08 & -3.905312 & 114.764456 & 128 & 75 & 0.837 & 1.19 & Sandy-clay \\
\hline$\Xi$ & & & & & 100 & 0.872 & 1.15 & \\
\hline 可 & & & & & 50 & 1.343 & 0.74 & Clay (with \\
\hline 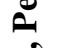 & BH-09 & -3.901929 & 114.769658 & 161 & 75 & 1.183 & 0.85 & water \\
\hline$\hat{z=}$ & & & & & 100 & 1.216 & 0.82 & content) \\
\hline ص & & & & & 50 & 0.954 & 1.05 & \\
\hline$\stackrel{00}{=}$ & BH-10 & -3.898559 & 114.773791 & 133 & 75 & 0.971 & 1.03 & \\
\hline ప્ટ & & & & & 100 & 0.998 & 1 & \\
\hline Е & & & & & 50 & 0.678 & 1.47 & Sandy-clay \\
\hline 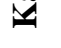 & BH-12 & -3.890369 & 114.784634 & 59 & 100 & 0.692 & 1.45 & \\
\hline & & & & & 120 & 0.666 & 1.5 & \\
\hline
\end{tabular}

A water retention curve illustrates how the water-bearing capacity of the soil reduces with increased water tension above the groundwater level.

In water retention curves, the volumetric water content is used. However, our acquired values will be stated in gravimetric water content. Gravimetric water content is the ratio between the mass of water and solid mass in a sample. Changes in water content over time are less for fine-grained soils such as clay and silt compared to more draining soils such as gravel and sand. Generally, soils with high organic content have a low heat convection capacity.

\section{CONCLUSION}

Based on the thermal conductivity value obtained, it can be concluded that,

1. Sandy-clay rocks dominate the spreading of the soil layers of the study area with thermal conductivity values $(\lambda$ $>1.2 \mathrm{~W} / \mathrm{mK}$ ) both in the Sapu Angin hill, sub-district Panyipatan and in the Kampung Baru, sub-district Pelaihari area.

2. The presence of carbonate minerals which have been transformed due to weathering can increase the value of thermal conductivity $(\lambda>2 \mathrm{~W} / \mathrm{mK})$ seen at locations BH-6 and BH-11.

3. A high water content in the soil layer can cause a decreasing in the value of 
thermal conductivity $(\lambda<1.2 \mathrm{~W} / \mathrm{mK})$ due to the weakening of bonds between soil particles that occur at several points of the study sites.

\section{REFERENCE}

American Society for Testing and Materials. (2005). Standart Test Method for Determination of Thermal Conductivity of Soil and Soft Rock by Thermal Needle Probe Procedure D 5334-08. ASTM International, 04, 1 6. https://doi.org/10.1520/D5334-08.2

Côté, J., and Konrad, J. M. (2005). A generalized thermal conductivity model for soils and construction materials. Canadian Geotechnical Journal, 42(2), 443 - 458. https://doi.org/10.1139/t04106

Dali Naidu, A., and Singh, D. N. (2004). A generalized procedure for determining thermal resistivity of soils. International Journal of Thermal Sciences, 43(1), 43 - 51. https://doi.org/10.1016/S12900729(03)00103-0

Darlan, Y., Zuraida, R., Purwanto, C., Sulistyanti, R., Setyabudhi, A. and Masduki, A. (1999). Studi Regional Cekungan Batubara Wilayah Pesisir Tanah Laut - Kotabaru Kalimantan Selatan. Direktorat Sumberdaya Mineral, Badan Geologi, Kementerian ESDM.

Herzen, G.V. and Maxwell, A. E. (1959). The measurement of thermal conductivity of Deep-Sea Sediments by a Needle-Probe Method. Journal of Geophysical Research, 64(10), 1557 1563.

https://doi.org/10.1098/rspa.1923.009
Lilliestierna, A., and Utas, J. (2015). Thermal classification of cable route. In Department of Civil and Environmental Engineering Division of GeoEngineering Chalmers University of Technology.

Malmedal, K., Bates, C., and Cain, D. (2014). The measurement of soil thermal stability, thermal resistivity, and underground cable ampacity. Papers Presented at the Annual Conference - Rural Electric Power Conference.

https://doi.org/10.1109/REPCon.2014. 6842210

Sundberg, J. (1988). Thermal properties of soils and rocks. In Göteborg: Chalmers University of Technology and University of Göteborg (Issue 686).

van Rooyen, M., and Winterkorn, H. F. (1957). Theoretical and Practical Aspects of the Thermal Conductivity of Soils and Similar Granular Systems. In Highway Research Board Bulletin 168 - Fundamental and Practical Concepts of Soil Freezing (Issue 168).

Vasile, M., and Vespremeanu-Stroe, A. (2017). Thermal Weathering and Distribution of Mountain Rockwalls. In Thermal Weathering and Distribution of Mountain Rockwalls (Issue January, pp. $\quad 765 \quad-120$ ). https://doi.org/10.1007/978-3-31932589-7

Zhang, N., and Wang, Z. (2017). Review of soil thermal conductivity and predictive models. International Journal of Thermal Sciences, 117, 172-183. https://doi.org/10.1016/j.ijthermalsci.2 017.03.013 